\title{
Comparative analysis of the pituitary and ovarian GnRH systems in the leopard gecko: signaling crosstalk between multiple receptor subtypes in ovarian follicles
}

\author{
Tadahiro Ikemoto and Min Kyun Park \\ Department of Biological Sciences, Graduate School of Science, The University of Tokyo, 7-3-1 Hongo, Bunkyo, Tokyo 113-0033, Japan \\ (Requests for offprints should be addressed to M K Park; Email: biopark @ biol.s.u-tokyo.ac.jp)
}

\begin{abstract}
$\mathrm{GnRH}$ regulates reproductive functions through interaction with its pituitary receptor in vertebrates. The present study demonstrated that the leopard gecko possessed two and three genes for GnRH ligands and receptors, respectively, though one of the three receptor subtypes had long been thought not to exist in reptiles. Each receptor subtype showed a distinct pharmacology. All types of ligands and receptors showed different expression patterns, and were widely expressed both inside and outside the brain. This report also shows a comparison of the pituitary and ovarian $\mathrm{GnRH}$ systems in the leopard gecko during and after the egg-laying season. All three receptor subtypes were expressed in both the whole pituitary and ovary; however, only one receptor subtype could be detected in the anterior pituitary gland. In situ hybridization showed spatial expression patterns of ovarian receptors, and suggested co-expression of multiple receptor subtypes in granulosa cells of larger follicles. Co-transfection of receptor subtypes showed a distinct pharmacology in COS-7 cells compared with those of single transfections. These results suggest that distinct signaling mechanisms are involved in the pituitary and ovarian $\mathrm{GnRH}$ systems. Seasonal and developmental variations in receptor expression in the anterior pituitary gland and ovarian follicles may contribute to the seasonal breeding of this animal.
\end{abstract}

Journal of Molecular Endocrinology (2007) 38, 289-304

\section{Introduction}

Gonadotropin-releasing hormone (GnRH) was originally identified as a hypothalamic decapeptide, which stimulates pituitary gonadotropes to synthesize and release gonadotropins (Matsuo et al. 1971, Burgus et al. 1972). The notion that multiple types of GnRH ligands and receptors are distributed in a wide range of tissues has become generally accepted. Thus, GnRH is thought to have diverse physiological functions in addition to the facilitation of gonadotropin secretion (Millar 2003).

In our previous studies, a GnRH ligand and a GnRH receptor (GnRHR) were identified in a reptile, the leopard gecko Eublepharis macularius (Ikemoto \& Park 2003, Ikemoto et al. 2004). Regarding the GnRHR, there were only trace levels of expression in the pituitary gland. This raised the question of whether this animal has at least one more GnRHR subtype highly expressed in the pituitary gland. The present study aimed to determine whether this species possesses multiple isoforms of GnRH ligands and receptors.

This report also describes the comparison of $\mathrm{GnRH}$ systems in the anterior pituitary gland and ovary in the leopard gecko. The expression of GnRHR in the ovary is well conserved in vertebrates. This may indicate that GnRH affects the ovary directly via the gonadal receptors as well as indirectly via the pituitary gland. Therefore, this study also aimed to compare the ovarian GnRH system with the pituitary one in this reptile.

The regulation of gonadal GnRHR expression during gametogenesis is poorly understood. The ovary of the adult leopard gecko is an ideal model for studying gene expression changes during follicular development and across seasons, as the large preovulatory follicles are arranged in a hierarchy according to size and the development of these follicles is tightly regulated. The preovulatory follicles mature from a very large pool of non-yellow yolk-containing oocytes of less than $1 \mathrm{~mm}$ diameter. Follicles are designated $\mathrm{F}_{1}, \mathrm{~F}_{2}$, and so forth, according to descending diameter. The largest follicle, designated $F_{1}$, is fully vitellogenic during the egg-laying season and will be ovulated next. Therefore, seasonal changes of GnRHR expression were examined in each type of ovarian follicle of the leopard gecko.

\section{Materials and methods}

\section{Animals}

Reproductively active leopard geckos of 1 year of age were studied. Animals were hatched in our laboratory and their incubation temperature was $29^{\circ} \mathrm{C}$. Animals 
were maintained at $29{ }^{\circ} \mathrm{C}$ with a long day photoperiod (14 $\mathrm{h}$ light and $10 \mathrm{~h}$ dark) during the egg-laying season and at $18{ }^{\circ} \mathrm{C}$ with a long day photoperiod after the egglaying season. Animals were provided with crickets, water, and powdered calcium supplement available ad libitum. Animals were killed by rapid decapitation. Tissues and organs were immediately dissected, frozen in liquid nitrogen, and stored at $-80^{\circ} \mathrm{C}$ until use. Vitellogenic follicles were punctured, and carefully washed in PBS ( $\mathrm{pH} \mathrm{7.4)}$ ) to remove the yolk.

\section{RNA and genomic DNA isolation and cDNA synthesis}

Total RNA and genomic DNA were extracted using ISOGEN (NIPPON GENE, Tokyo, Japan). The cDNAs used as templates for RT-PCR were synthesized from $1 \mu \mathrm{g}$ denatured total RNA using $5 \mu \mathrm{M}$ oligo(dT) primer and 100 units M-MLV reverse transcriptase (Promega) in a $20-\mu \mathrm{l}$ reaction volume with incubation at $42^{\circ} \mathrm{C}$ for $1.5 \mathrm{~h}$, and were subsequently diluted 6 -fold. The cDNAs used as templates for rapid amplification of cDNA ends (RACE) were synthesized as described previously (Ikemoto et al. 2004).

\section{Molecular cloning of the GnRH-I cDNA and gene using the synteny relationship}

The conserved synteny relationship between the gene encoding GnRH-I ( $G n R H-I)$ and the gene for potassium channel tetramerization domain containing 9 (KCTD9) (Okubo et al. 2002) was used to identify the molecular form of GnRH-I in the leopard gecko. PCR amplification was carried out using genomic DNA to obtain the sequence between the two genes. Degenerate primers, KCTD9-DS and GnRH-DA (Table 1), were used for this amplification. All of the following PCR amplifications were performed in a $20-\mu \mathrm{l}$ reaction mixture containing each primer at $1 \mu \mathrm{M}, 0.25$ units of TaKaRa Ex Taq (TaKaRa, Shiga, Japan), each dNTP at $250 \mu \mathrm{M}$, and Ex Taq Buffer (TaKaRa). The reaction conditions were as follows: $94{ }^{\circ} \mathrm{C}$ for 5 min followed by 45 cycles of $94.3^{\circ} \mathrm{C}$ for $45 \mathrm{~s}, 60^{\circ} \mathrm{C}$ for $25 \mathrm{~s}$, and $72{ }^{\circ} \mathrm{C}$ for $4 \mathrm{~min}$. The single PCR product was obtained by electrophoresis on a $1.0 \%$ Tris-acetate-EDTA agarose gel, visualized with ethidium bromide staining on a FAS-III system (TOYOBO, Osaka, Japan), extracted using phenol and chloroform, and directly sequenced. This was independently repeated three times to avoid any PCR amplification

Table 1 Oligonucleotide primers

\begin{tabular}{|c|c|c|}
\hline & Nucleotide sequence $^{a}$ & Target \\
\hline \multicolumn{3}{|l|}{ Name } \\
\hline KCTD9-DS & 5'-TTTGARGAGATGCTGACNCC -3' & KCTD9 \\
\hline GnRH-DA & $5^{\prime}$-NNNNCKYTTNCCNCCNGG -3' & GnRH-I \\
\hline $\mathrm{I}-1 \mathrm{~A}$ & $5^{\prime}$-GGAAGCTTGTGAGCAAGCTCCCCAT $-3^{\prime}$ & GnRH-I \\
\hline $\mathrm{I}-1 \mathrm{~S}$ & 5'-ATGGGGAGCTTGCTCACAAGCTTCC -3' & $\mathrm{GnRH}-\mathrm{I}$ \\
\hline $\mathrm{I}-2 \mathrm{~A}$ & $5^{\prime}$-AATGTTGATAATCTTTATTGATGAA - $3^{\prime}$ & GnRH-I \\
\hline R-DS & $5^{\prime}$-GGNHTNTGGTACTGGTT $-3^{\prime}$ & GnRHR \\
\hline $\mathrm{R} 1-1 \mathrm{~A}$ & $5^{\prime}$-GTAGATTACAGGATCCAGGCAGGCA -3' & GnRHR1 \\
\hline R3-1A & 5'-TAGATGATGGGGTCAAGGCACGCGT $-3^{\prime}$ & GnRHR3 \\
\hline $\mathrm{R} 1-1 \mathrm{~S}$ & $5^{\prime}$-ACACCCCTCCCAGCTTCCCAAGGCT $-3^{\prime}$ & GnRHR1 \\
\hline $\mathrm{R} 1-2 \mathrm{~A}$ & $5^{\prime}$-AGCCCCAGCTGTCAGTCTGTCTCAC - $3^{\prime}$ & GnRHR1 \\
\hline R3-1S & 5'-TCAAGGGGGGAGCCTCTTTAACAGG -3' & GnRHR3 \\
\hline R3-2A & 5'-GAGAAATATTCTGTATTTATTGGTT - $3^{\prime}$ & GnRHR3 \\
\hline R1-start & 5'-GTGGTGGAATTCGCCACCATGGTCCCAGAGATGAATACCAGT -3' & GnRHR1 \\
\hline R1-end & $5^{\prime}$-TCTAGACTCGAGAGCCCCAGCTGTCAGTCTGTCTCACAAGC - $3^{\prime}$ & GnRHR1 \\
\hline R3-start & $5^{\prime}$-CCGAGCTCGGATCCGCCACCATGAACACCACCTTCCCAATGAAG -3' & GnRHR3 \\
\hline R3-end & 5'-TATCTGCAGAATTCAGTAGACAAGTGACTCCTCCTGTCCCTTCA -3' & GnRHR3 \\
\hline R1-2S & $5^{\prime}$-GGATATGGCTTGCCGGCTGCTCATG $-3^{\prime}$ & GnRHR1 \\
\hline R1-CompA & 5'-GGCAGCTCCATAGCAGACAGGGTGCCAGCGCTGGGCAAAGGATCCC $-3^{\prime}$ & GnRHR1 \\
\hline$R 1-3 A$ & $5^{\prime}$-GGCAGCTCCATAGCAGACAGGGTGC $-3^{\prime}$ & GnRHR1 \\
\hline R2-S & 5'-CGGCGACGCCCTGTGCAAAATCTTG -3' & GnRHR2 \\
\hline R2-CompA & 5'-TCCGGCATCTGACTGATCATGTCGGGCCTTGGAAATGTGGTCGTCTT -3' & GnRHR2 \\
\hline R2-A & $5^{\prime}$-TCCGGCATCTGACTGATCATGTCGG $-3^{\prime}$ & GnRHR2 \\
\hline R3-2S & 5'-CGTAGCCTGCCGGCTTCTCATGTTC - $3^{\prime}$ & GnRHR3 \\
\hline R3-CompA & $5^{\prime}$-CTCTAGACTTGGGTGGAGCACAAGCATGAAAACTTCCCACAGTGGC $-3^{\prime}$ & GnRHR3 \\
\hline R3-3A & $5^{\prime}$-CTCTAGACTTGGGTGGAGCACAAGC $-3^{\prime}$ & GnRHR3 \\
\hline $124-S$ & 5'-TCGCCTGTCAACGCGCAGGACTTCT -3' & c-fos \\
\hline $489-A$ & $5^{\prime}$-ATCAGTCAGCTCCCTCCTCCGGTTG -3' & c-fos \\
\hline CompA & 5'-ATCAGTCAGCTCCCTCCTCCGGTTGGAGATAACTGTTCCACCTTGCC -3' & c-fos \\
\hline $\mathrm{I}-2 \mathrm{~S}$ & $5^{\prime}$-GATAGAATCTTTCCAAGAGATTGCA $-3^{\prime}$ & $\mathrm{GnRH}-\mathrm{I}$ \\
\hline $\mathrm{I}-3 \mathrm{~A}$ & $5^{\prime}$-GTGGTTGTATTTCTTTTGTGGAAAT -3' & GnRH-I \\
\hline
\end{tabular}

Kozak consensus sequence is underlined.

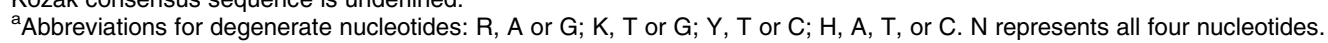


errors. After determination of the partial sequence of GnRH-I, the full-length cDNA sequence was determined by RACE according to the manufacturer's instructions using whole brain cDNAs obtained from three animals. Primers, I-1A and I-S (Table 1), were used for $5^{\prime}$-RACE and $3^{\prime}$-RACE, respectively. The products amplified were sequenced as above.

The reminder of the sequence of GnRH-I was determined after PCR amplification with I-1S and I-2A (Table 1). The reaction conditions were as follows: $94{ }^{\circ} \mathrm{C}$ for $5 \mathrm{~min}$ followed by 45 cycles of $94 \cdot 3^{\circ} \mathrm{C}$ for $45 \mathrm{~s}$, $65^{\circ} \mathrm{C}$ for $25 \mathrm{~s}$, and $72{ }^{\circ} \mathrm{C}$ for $2 \mathrm{~min}$.

\section{Molecular cloning of the GnRHR cDNAs and genes}

The whole brain cDNAs were amplified by 3'-RACE according to the manufacturer's instructions using R-DS (Table 1) to obtain partial sequences of GnRHRs. Two putative GnRHR sequences (designated GnRHRs 1 and 3 ) were identified in addition to the sequence previously identified (Ikemoto et al. 2004). Full-length cDNA sequences were then determined by $5^{\prime}$-RACE using the whole brain cDNAs with R1-1A for GnRHR1 and R3-1A for GnRHR3 (Table 1).

The genomic sequences of the genes encoding GnRHRs were determined after PCR amplification with R1-1S and R1-2A for GnRHR1, and R3-1S and R3-2A for GnRHR3 (Table 1). The reaction conditions were as follows: $94^{\circ} \mathrm{C}$ for 5 min followed by 45 cycles of $94 \cdot 3{ }^{\circ} \mathrm{C}$ for $45 \mathrm{~s}, 65^{\circ} \mathrm{C}$ for $25 \mathrm{~s}$, and $72^{\circ} \mathrm{C}$ for $2 \mathrm{~min}$.

Transmembrane (TM) domains and N-linked glycosylation sites were predicted using the CBS prediction servers (http://www.cbs.dtu.dk/services/).

\section{Cell culture, plasmid transfection, and ligand stimulation}

COS-7 cells were a generous gift from Cell Resource Center for Biomedical Research, Institute of Development, Aging and Cancer, Tohoku University (Sendai, Japan). COS-7 cells were maintained at $37^{\circ} \mathrm{C}$ in a humidified atmosphere of $5 \% \mathrm{CO}_{2} / 95 \%$ air in lowglucose Dulbecco's modified Eagle's medium (DMEM) supplemented with $10 \%(\mathrm{v} / \mathrm{v})$ fetal bovine serum (Invitrogen).

The entire open reading frame (ORF) sequences of the cloned receptors were amplified using the whole brain cDNAs with R1-start and R1-end for GnRHR1 and R3-start and R3-end for GnRHR3 (Table 1), and cloned into a mammalian expression vector, pcDNA3.1 (Invitrogen). To ensure efficient and similar translation for all the three GnRHRs, a Kozak consensus sequence (CGCCACC) was placed immediately upstream of the translation initiation codon (Table 1). After confirmation of the sequences, each plasmid DNA was transiently transfected into monolayer cultures of COS-7 cells in $60 \mathrm{~mm}$ dishes using TransFast Transfection Reagent (Promega). After $24 \mathrm{~h}$, the cells were serum-starved by replacing the medium with fresh DMEM without serum and further cultured for an additional $24 \mathrm{~h}$. Subsequently, the cells were gently stimulated with a $\mathrm{GnRH}$ peptide for $30 \mathrm{~min}$. The GnRH peptides used were chicken GnRH-I (cGnRH-I) and cGnRH-II (Sigma-Aldrich). At the end of the culture, the medium was removed, and cells were lysed with ISOGEN. Total RNA was isolated, and cDNA was synthesized as above. As a negative control, an experiment in which COS-7 cells were transfected with blank vector only and then treated with a GnRH peptide was also conducted. Experiments were performed independently at least three times. To examine whether the receptor expression levels were similar in replicate experiments, the cDNAs were amplified with R1-2S and R1-3A for GnRHR1, R2-S and R2-A for GnRHR2, and R3-2S and R3-3A for GnRHR3. PCR products were electrophoresed, visualized with ethidium bromide staining on a FAS-III system, and the optical densities of bands were determined using Scion Image for Windows (version beta 4.02) (Scion Corporation, Frederick, MD, USA). The amount of DNA transfected in single transfection experiments was $6 \mu \mathrm{g}$. The total amount of DNA transfected in co-transfection experiments was kept constant at $6 \mu \mathrm{g}$ by the addition of blank vector. The data obtained were analyzed using GraphPad Prism software (version 3.0) (GraphPad Software, San Diego, CA, USA). Median effective concentration $\left(\mathrm{EC}_{50}\right)$ values and maximal response were estimated using nonlinear regression curve fit.

\section{Construction of the competitor DNAs}

The competitor DNAs for the competitive PCR were constructed as described previously (Ikemoto \& Park 2007). Briefly, the GnRHR competitor DNAs were constructed using the whole brain cDNAs from the leopard gecko with R1-2S and R1-CompA for GnRHR1, R2-S and R2-CompA for GnRHR2, and R3-2S and R3-CompA for GnRHR3. The c-fos competitor DNA was constructed using the cDNAs from COS-7 cells with 124-S and CompA (Table 1). The GnRHR sequences were amplified using the whole brain cDNAs from the leopard gecko with R1-2S and R1-3A for GnRHR1, R2-S and R2-A for GnRHR2, and R3-2S and R3-3A for GnRHR3. The c-fos sequence was amplified using the cDNAs from COS-7 cells with 124-S and 489-A.

\section{Competitive PCR}

Competitive PCR was carried out as described previously (Ikemoto \& Park 2007). Briefly, $1 \mu$ l of each 
diluted RT product or genomic DNA was amplified in the presence of various amounts of competitor using R1-2S and R1-3A for GnRHR1, R2-S and R2-A for GnRHR2, and R3-2S and R3-3A for GnRHR3, and 124-S and 489-A for c-fos.

\section{Molecular phylogenetic analysis and amino acid comparison of GnRHRs}

The CLUSTAL X program (version 1.81) (Thompson et al. 1997) was used with default settings to align the entire ORF nucleotide and amino acid sequences. The phylogenetic tree of GnRHRs was constructed based on the nucleotide alignment using the neighbor-joining method (Saitou \& Nei 1987) with the Mega software (version 3.1) (Kumar et al. 2004). Bootstrap values were calculated from 1000 replications to estimate the robustness of internal branches. The amino acid sequence identities were calculated using the GeneDoc software (version 2.6.002; http://www.psc.edu/biomed/genedoc/).

\section{Expression analysis of the GnRH ligand and receptor mRNAs}

To identify sites where the cloned genes might be expressed and obtain clues about the potential functions of GnRH, the spatial expression patterns of the GnRH ligands and receptors were examined using the RT-PCR-sequencing method. Each RT product was amplified with I-2S and I-3A for GnRH-I, R1-2S and R13A for GnRHR1, R2-S and R2-A for GnRHR2, and R3-2S and R3-3A for GnRHR3. These primers were designed to span two exon-intron boundaries. For negative controls, PCR amplifications were also conducted using each RNA sample without the RT reaction. The conditions were as follows: $94^{\circ} \mathrm{C}$ for $5 \mathrm{~min}$, followed by 45 cycles of $94{ }^{\circ} \mathrm{C}$ for $40 \mathrm{~s}, 65^{\circ} \mathrm{C}$ for $25 \mathrm{~s}$, and $72^{\circ} \mathrm{C}$ for $40 \mathrm{~s}$. The PCR products were analyzed as above. Each DNA fragment was extracted from the gel and sequenced directly to confirm that it was derived from the corresponding mRNA. Seasonal expression changes of the GnRHR mRNAs in the anterior pituitary gland and ovary were quantified by competitive PCR as above.

\section{In situ hybridization}

To examine the cell type-specific expression of the GnRHR mRNA in the ovary during the egg-laying season, whole-mount in situ hybridization was performed using digoxigenin-labeled RNA probe, according to the manufacturer's instructions (Roche Diagnostics). For the template of RNA probe, the ovarian cDNA was amplified with R1-2S and R1-3A for GnRHR1, R2-S and R2-A for GnRHR2, and R3-2S and R3-3A for GnRHR3. Each product amplified was extracted as above, and cloned into a pGEM-T vector (Promega). As a negative control, experiments with a labeled sense probe were also

ATGGGGAGCTTGCTCACAAGCTTCCTTCTGTTGCTTCTGTGTGTGGCAATTGGCTCGGCACAGCACTGGTCCTACGGCTTACAACCTGGA 149

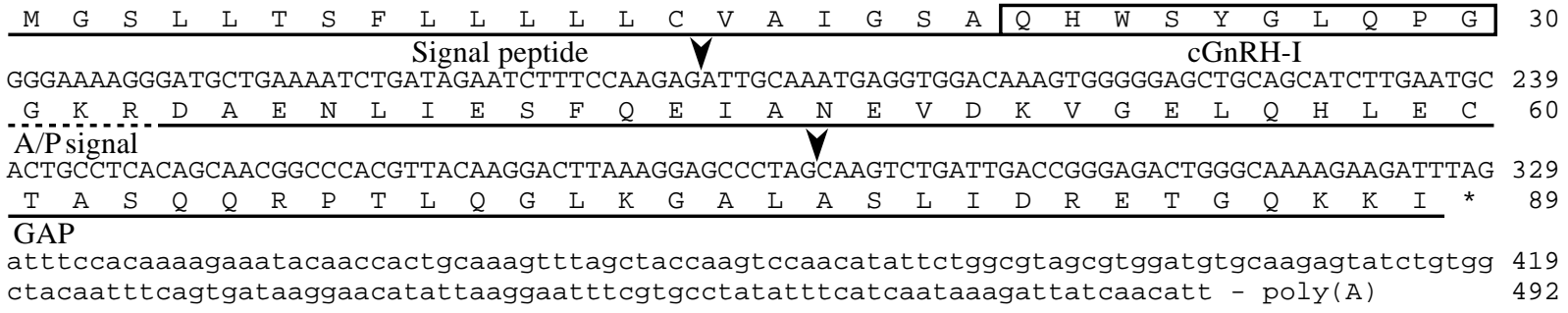

B

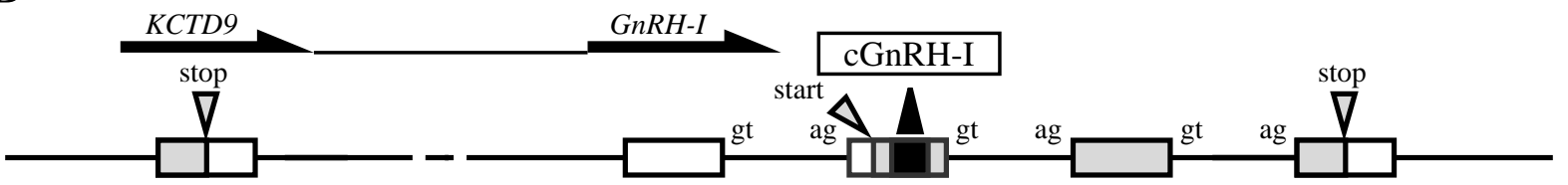

Figure 1 The cDNA and gene encoding prepro-GnRH-I polypeptide in the leopard gecko. (A), Nucleotide and deduced amino acid sequence of the cDNA encoding prepro-cGnRH-I polypeptide. Nucleotides (top) are numbered from $5^{\prime}$ to $3^{\prime}$. The ORF is indicated by capital letters, and the $5^{\prime}$ - and $3^{\prime}$-UTRs are indicated by lower case. Amino acid residues (bottom) are numbered beginning with the first methionine residue in the ORF. The asterisk indicates the stop codon. The cGnRH-I decapeptide is depicted in the open box. Arrowheads indicate the splice sites. A/P signal, amidation/proteolytic processing signal; GAP, GnRH-associated peptide. (B), Schematic diagram of the chromosomal gene arrangement around the $\mathrm{GnRH}-\mathrm{I}$. The $\mathrm{GnRH}$-l gene is adjacent to the gene for potassium channel tetramerization domain containing 9 (KCTD9). All the introns have the consensus $5^{\prime}$-GT and $3^{\prime}$-AG sequences. The ORF region is shaded. 
conducted. Sections were stained with methyl green solution for counter staining the cells.

\section{Results}

\section{Molecular identification of GnRH-I in the leopard gecko}

The molecular form of GnRH-I in the leopard gecko was identified as cGnRH-I based on the conserved synteny relationship between KCTD9 and GnRH-I (Fig. 1). The cDNA sequence data of the leopard gecko GnRH-I has been submitted to the DDBJ/EMBL/GenBank databases under accession no. DQ269480. The prepro-GnRH-I of the leopard gecko had structural characteristics of prepro-GnRH polypeptides: a signal peptide, a GnRH decapeptide (cGnRH-I), an amidation/proteolytic processing signal (glycine-lysine-arginine), and a GnRH-associated peptide (GAP). The signal peptide included a high proportion of hydrophobic amino acids, which is generally common for signal peptides of preproGnRH polypeptides in other species (Ikemoto \& Park 2006). The glycine-lysine-arginine sequence that followed the cGnRH-I decapeptide was identical to those of all the reported vertebrate prepro-GnRH polypeptides; the glycine residue is the standard donor of the amino group for carboxyl terminal amidation, and the dibasic sequence functions in proteolytic processing, as is also true for many neuroendocrine peptide precursors (Douglass et al. 1984).

Sequencing of the PCR-amplified leopard gecko GnRH-I revealed that it was composed of four exons (designated exons 1-4) separated by three introns at similar positions as found in other GnRHs (Fig. 1). The exon-intron boundaries were determined by sequence comparison with the corresponding cDNA. All of the three $5^{\prime}$ - and $3^{\prime}$-splice sites corresponded to the consensus sequences: $5^{\prime}$-GT (donor) and $3^{\prime}$-AG (acceptor) intron splice sites (Mount 1982). The

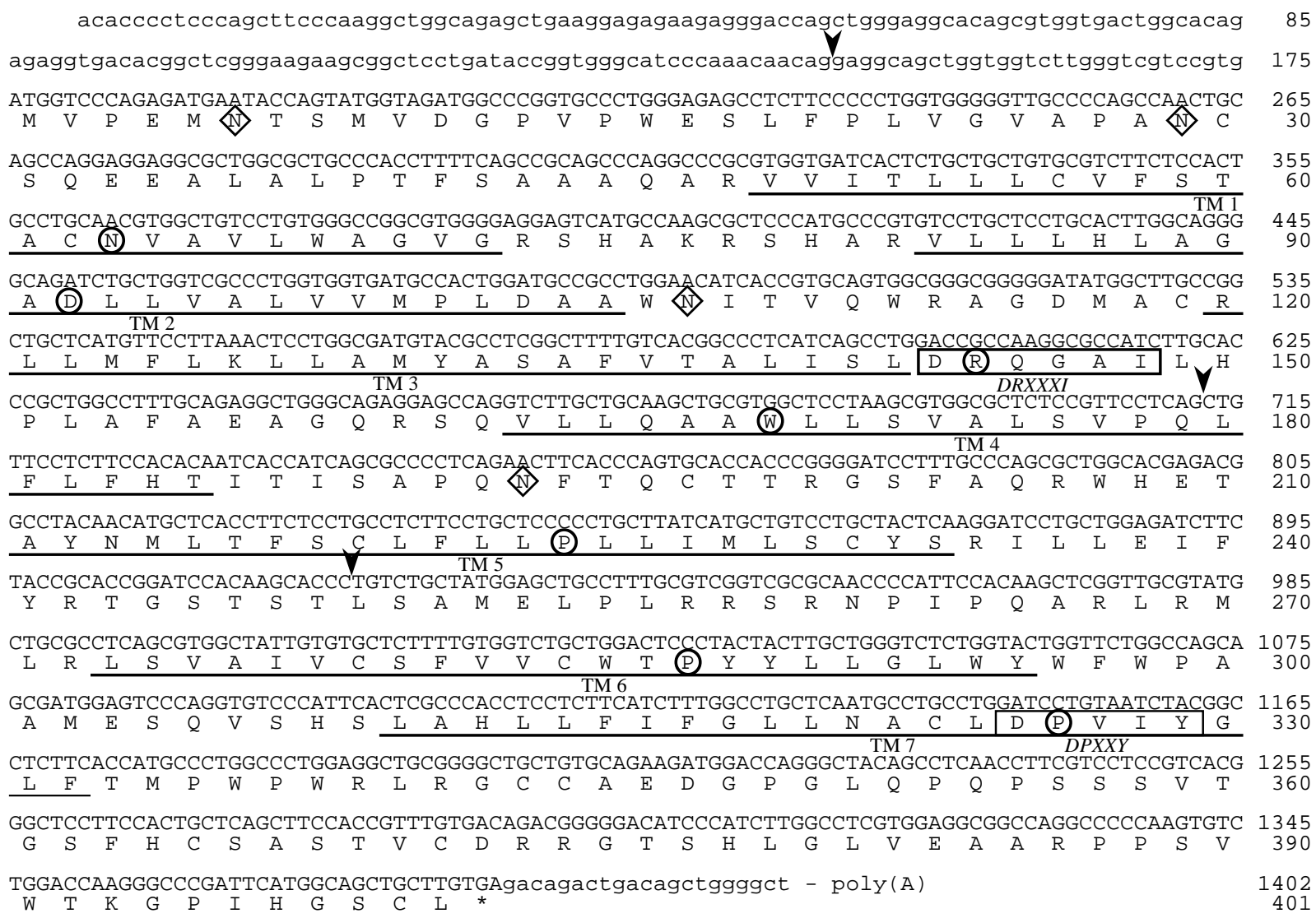

Figure 2 Nucleotide and deduced amino acid sequence of the cDNA encoding GnRHR1 in the leopard gecko. Nucleotides (top) are numbered from $5^{\prime}$ to $3^{\prime}$. The ORF is indicated by capital letters, and the $5^{\prime}$ - and $3^{\prime}$-UTRs are indicated by lower case. Amino acid residues (bottom) are numbered beginning with the first methionine residue in the ORF. The asterisk indicates the stop codon. Putative seven hydrophobic TM domains are underlined. Putative $N$-linked glycosylation sites with high probabilities (CBS prediction server score $>0 \cdot 50$ ) are indicated by diamonds. Arrowheads indicate the splice sites. The microdomain DRXXXI/V at the junction of TM3 and IC2 and the microdomain DPXXY in TM7 are depicted in open boxes. The most highly conserved residues in each helix in the Ballesteros-Weinstein numbering scheme (Ballesteros et al. 1998) are indicated by circles. 
three introns were located in the $5^{\prime}$-UTR, in the middle of GAP, and shortly upstream of the $3^{\prime}$-UTR, respectively. Exon 1 contained a part of the $5^{\prime}$-UTR. Exon 2 encoded the rest of the $5^{\prime}$-UTR, signal peptide, GnRH decapeptide, amidation/proteolytic processing signal, and a part of GAP. Exon 3 encoded the central portion of GAP. Exon 4 encoded the rest of GAP along with the $3^{\prime}$-UTR. The structure of all known vertebrate $G n R H \mathrm{~s}$ is well conserved and is composed of four exons and three introns (Ikemoto \& Park 2006).

\section{Identification of three types of GnRHRs in the leopard gecko}

Two putative GnRHR sequences designated GnRHR1 and GnRHR3 were identified from the leopard gecko in addition to the sequence identified in our previous study (Ikemoto et al. 2004; Figs 2 and 3). The cDNA sequence data of the leopard gecko GnRHR1 and GnRHR3 have been submitted to the DDBJ/EMBL/ GenBank databases under accession nos. DQ269481 and DQ269482. Exon-intron boundaries were determined by comparison between the genomic sequences and the sequences of the corresponding cDNAs. All three leopard gecko GnRHRs had seven hydrophobic TM domain structures, which is a characteristic of $\mathrm{G}$ protein-coupled receptors (GPCRs). All three GnRHRs had distinct genomic structures. GnRHR1, GnRHR2, and GnRHR3 consisted of 4, 5, and 3 exons respectively (Fig. 4; Ikemoto et al. 2004). All three GnRHRs in the leopard gecko contained three exons in the ORF (designated exons 1, 2, and 3) separated by two introns (designated introns 1 and 2) in TM4 and the third intracellular loop (IC3), at the same positions as those of all other reported GnRHRs

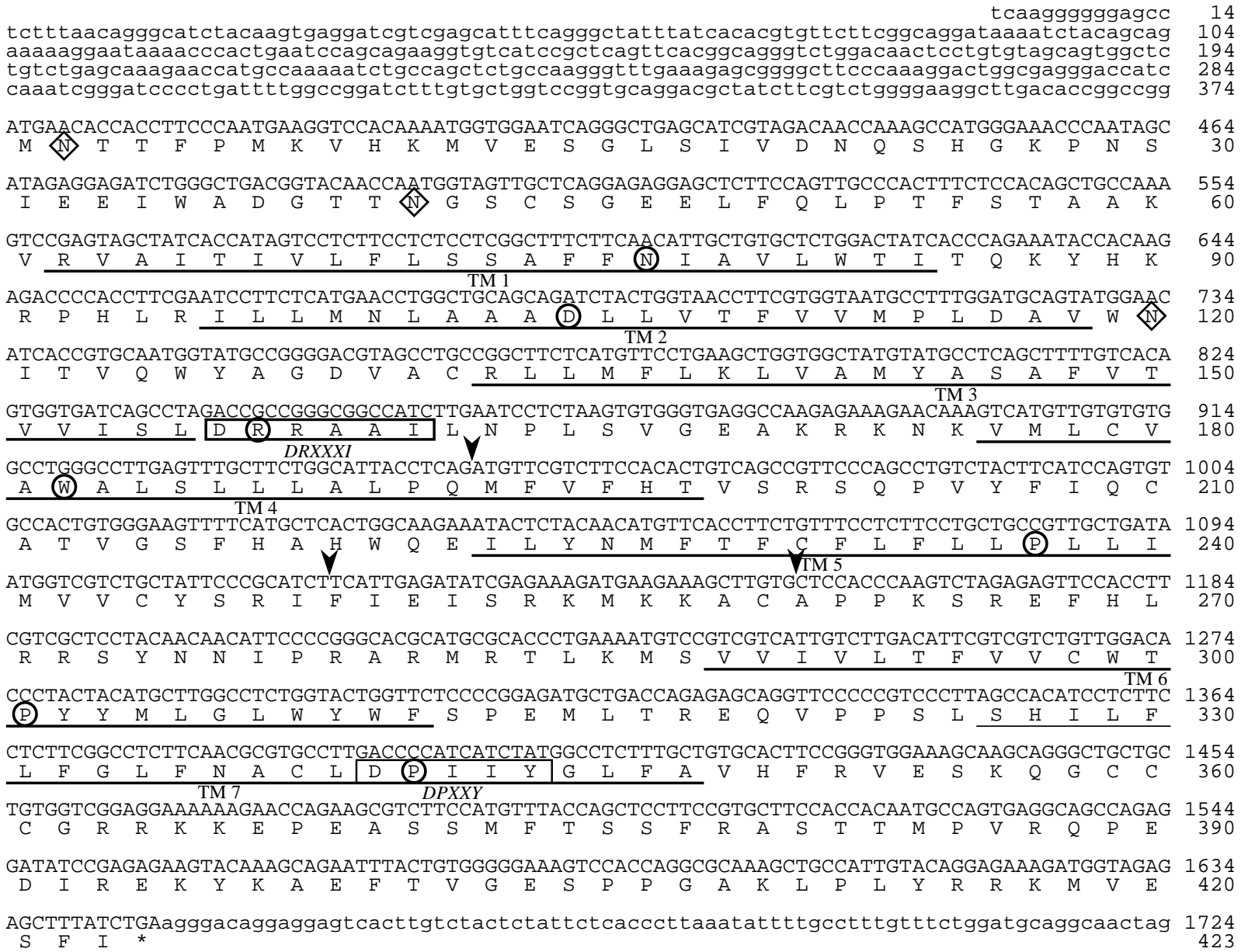

Figure 3 Nucleotide and deduced amino acid sequence of the cDNA encoding GnRHR3 in the leopard gecko. For details, see the legend to Fig. 2. 

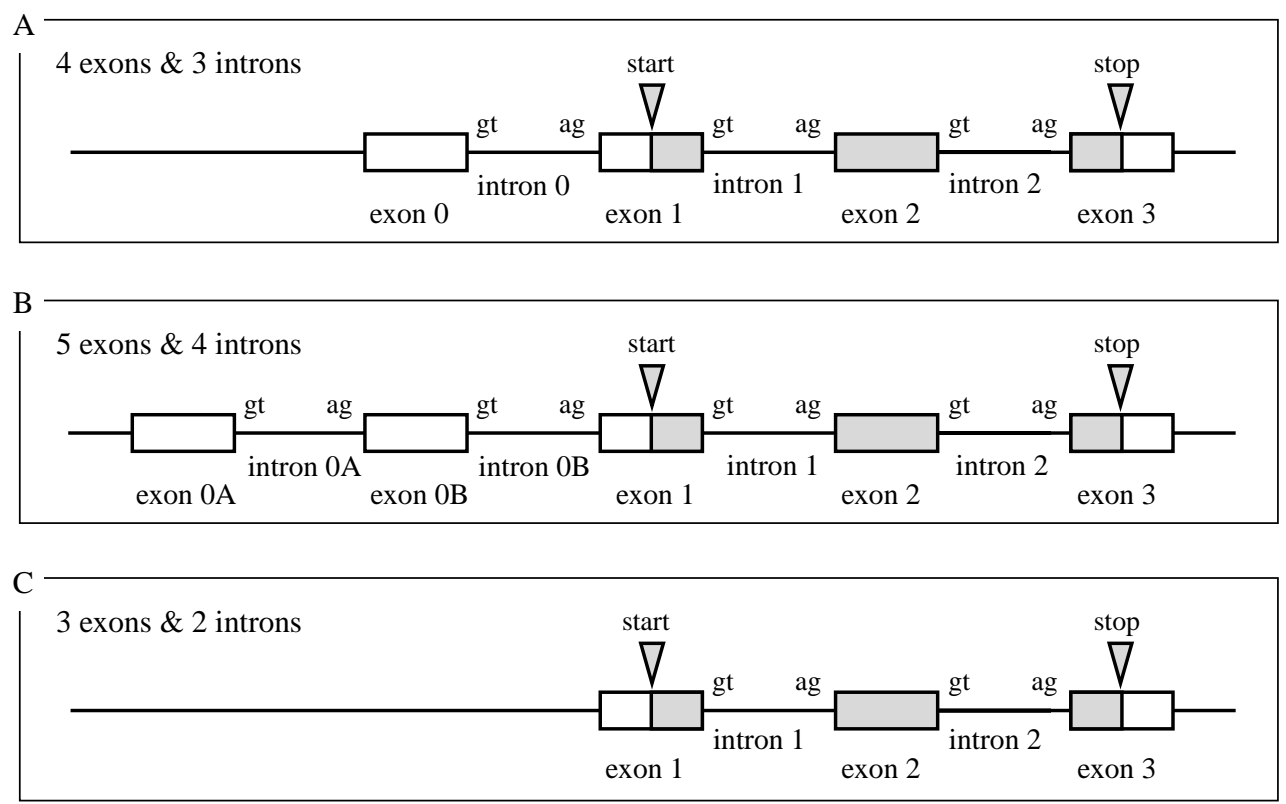

Figure 4 Schematic diagrams of the GnRHR1 (A), GnRHR2 (B), and $G n R H R 3(\mathrm{C})$ genes in the leopard gecko. Boxes and horizontal lines indicate exons and introns respectively. Each ORF region is shaded. All the introns have the consensus $5^{\prime}$-GT and $3^{\prime}$-AG sequences.

(Ikemoto \& Park 2005a). Some GnRHRs have additional intron(s) before intron 1 (Ikemoto et al. 2004). GnRHR1 and GnRHR2 had one and two additional introns before intron 1 respectively (Ikemoto et al. 2004). All of the $5^{\prime}$ and $3^{\prime}$-splice sites corresponded to the consensus sequences (Mount 1982).

\section{Pharmacological differences of the leopard gecko GnRHRs}

GnRH induced c-fos expression in COS-7 cells transiently transfected with the leopard gecko GnRHR, in a dose- and ligand-dependent manner (Fig. 5). Both cGnRH-I and cGnRH-II, native GnRH forms in the leopard gecko (Ikemoto \& Park 2003), upregulated $c$ fos expression. Expression levels of receptors transfected were similar in replicate experiments. The enhancement at the highest dose tested was approximately $2 \cdot 86-, 12 \cdot 0$-, and $3 \cdot 92$-fold over basal in cells with GnRHR1, GnRHR2, and GnRHR3, respectively (Fig. 5 and Table 2). In cells with GnRHR1 and GnRHR2, cGnRH-II was $1 \cdot 89$ - and 150-fold more potent than cGnRH-I, respectively (Fig. 5B and D and Table 2). In contrast, no statistically significant
A

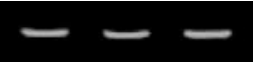

B

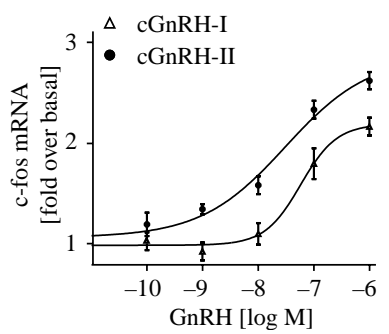

$\mathrm{C}$

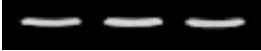

$\mathrm{D}$

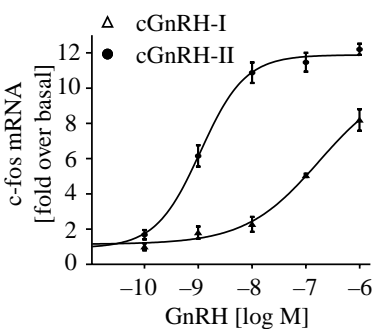

E

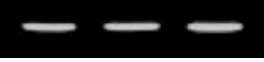

F

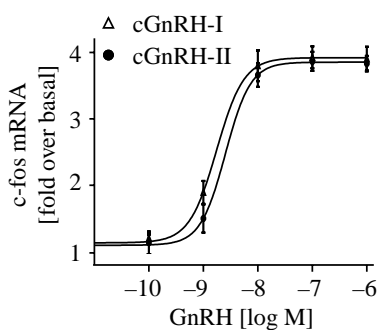

Figure $5 \mathrm{GnRH}$-induced c-fos mRNA expression in COS-7 cells transiently transfected with the leopard gecko GnRHR1 (A, B), GnRHR2 (C, D), and GnRHR3 (E, F). RT-PCR products were visualized with ethidium bromide staining, and the optical densities of bands were analyzed $(A, C, E)$. GnRH upregulated the $c$-fos mRNA expression level in a dose- and ligand-dependent manner (B, D, F). Data represent the mean \pm S.E.M. from at least three independent experiments. 
Table 2 GnRH-induced c-fos mRNA expression in COS-7 cells transiently transfected with each GnRHR of the leopard gecko

\begin{tabular}{|c|c|c|c|}
\hline & Ligand & $\mathrm{EC}_{50}(\mathrm{nM})$ & Max fold induction \\
\hline \multirow[t]{2}{*}{ GnRHR1 } & cGnRH-I & $58 \cdot 27 \pm 5 \cdot 61$ & $2 \cdot 19 \pm 0.14$ \\
\hline & cGnRH-II & $30 \cdot 82 \pm 6 \cdot 11$ & $2 \cdot 86 \pm 0.35$ \\
\hline \multirow{2}{*}{ GnRHR2 } & cGnRH-I & $173 \cdot 6 \pm 11 \cdot 1$ & $10 \cdot 5 \pm 3.3$ \\
\hline & cGnRH-II & $1 \cdot 154 \pm 0.124$ & $12 \cdot 0 \pm 0.2$ \\
\hline \multirow{2}{*}{ GnRHR3 } & cGnRH-I & $1.755 \pm 1.294$ & $3.92 \pm 0.13$ \\
\hline & cGnRH-II & $2.557 \pm 1.380$ & $3.85 \pm 0.16$ \\
\hline
\end{tabular}

difference could be observed between cGnRH-I and cGnRH-II stimulations in cells with GnRHR3 (Fig. 5F and Table 2). Cells transfected with blank vector alone did not show significant induction of $c$-fos expression (data not shown).

\section{Molecular phylogenetic analysis of GnRHRs}

The molecular phylogenetic tree of GnRHRs is shown in Fig. 6. Vertebrate GnRHRs are classified into four types (1/III, 2/nmI, 3/II, and $4 / \mathrm{mI})$ as described previously (Ikemoto et al. 2004, Ikemoto \& Park 2005a). Analysis using conserved seven TM domains yielded essentially the same tree topology. The three GnRHRs of the leopard gecko were divided into three types: 1/III, 2/nmI, and 3/II. The type 4/mI GnRHRs were definitely separated from other three types of GnRHRs by the tunicate GnRHRs used as outgroup.

\section{Comparison of the deduced amino acid sequences of GnRHRs}

The percentages of the entire ORF amino acid identities were calculated from the alignment of GnRHRs of the leopard gecko and other representative species (Table 3). As inferred from the results of the phylogenetic analysis, each type of the leopard gecko GnRHR shared higher identities with GnRHRs of the corresponding type.

\section{Expression of the GnRH ligand and receptor mRNAs in the leopard gecko}

Single products were obtained from RT-PCR of GnRH-I, GnRHR1, and GnRHR3 in the leopard geckos of 1 year of age during the egg-laying season (Fig. 7). The possibility of genomic contamination was eliminated by the observation of amplifications spanning two exonintron boundaries. No products were detected from any negative controls without the RT reaction. All the genes cloned in the present study showed different expression patterns, and were widely expressed both inside and outside the brain.

\section{Seasonal expression changes of the GnRHR mRNAs in the anterior pituitary gland and ovary}

Figure 8 shows the expression of GnRHRs in the anterior pituitary gland and ovary of the leopard geckos of 1 year of age. The anterior pituitary gland expressed only GnRHR1. Meanwhile, the ovary expressed all the three GnRHRs. The expression level of GnRHR1 in the anterior pituitary gland after the egg-laying season showed an $88 \%$ decrease compared with that during the egg-laying season. In the ovary, the expression level of GnRHR2 increased 4-fold after the egg-laying season, and the other receptor types did not show significant expression changes.

Figure 9 shows the expression of GnRHRs in the ovarian follicles of the leopard geckos of 1 year of age. Regarding GnRHR2, all the follicles during the egglaying season showed lower expression levels compared with the follicles in the corresponding hierarchical order after the egg-laying season. The largest follicle, designated $F_{1}$, showed the lowest expression levels of all the three GnRHRs during the egg-laying season compared with the other follicles during and after the egg-laying season.

\section{Spatial expression pattern of the GnRHR mRNAs in the ovary}

In situ hybridization showed spatial expression patterns of the GnRHR mRNAs in the ovary of the leopard gecko of 1 year of age during the egg-laying season (Fig. 10). Regarding GnRHR1, the antisense probe generated hybridization signals in granulosa cells, interstitial cells, and immature oocytes (Fig. 10A-C). Regarding GnRHR2, the antisense probe generated hybridization signals in granulosa cells, theca cells, interstitial cells, and immature oocytes (Fig. 10D-F). Regarding GnRHR3, hybridization signals were predominantly detected in granulosa cells (Fig. 10G). Granulosa cell layers of larger follicles $\left(\mathrm{F}_{2}\right.$ and $\mathrm{F}_{3}$ follicles $)$ showed strong signals for all three receptor subtypes (Fig. 10A, $\mathrm{D}$ and $\mathrm{G})$. The sense probes produced no hybridization signals (data not shown).

\section{Co-transfection of GnRHR subtypes showed a distinct pharmacology}

Figure 11 shows the GnRH-induced c-fos mRNA expression in COS-7 cells transiently transfected with multiple GnRHR subtypes of the leopard gecko. Co-transfection of GnRHR1 and GnRHR3 showed a decrease in estimated $\mathrm{EC}_{50}$ values and/or an enhancement in the estimated maximal induction compared with each single transfection. The $c$-fos induction was observed at a lower dose (Fig.11C and D; Table 4). Co-transfection of three GnRHR subtypes stimulated 


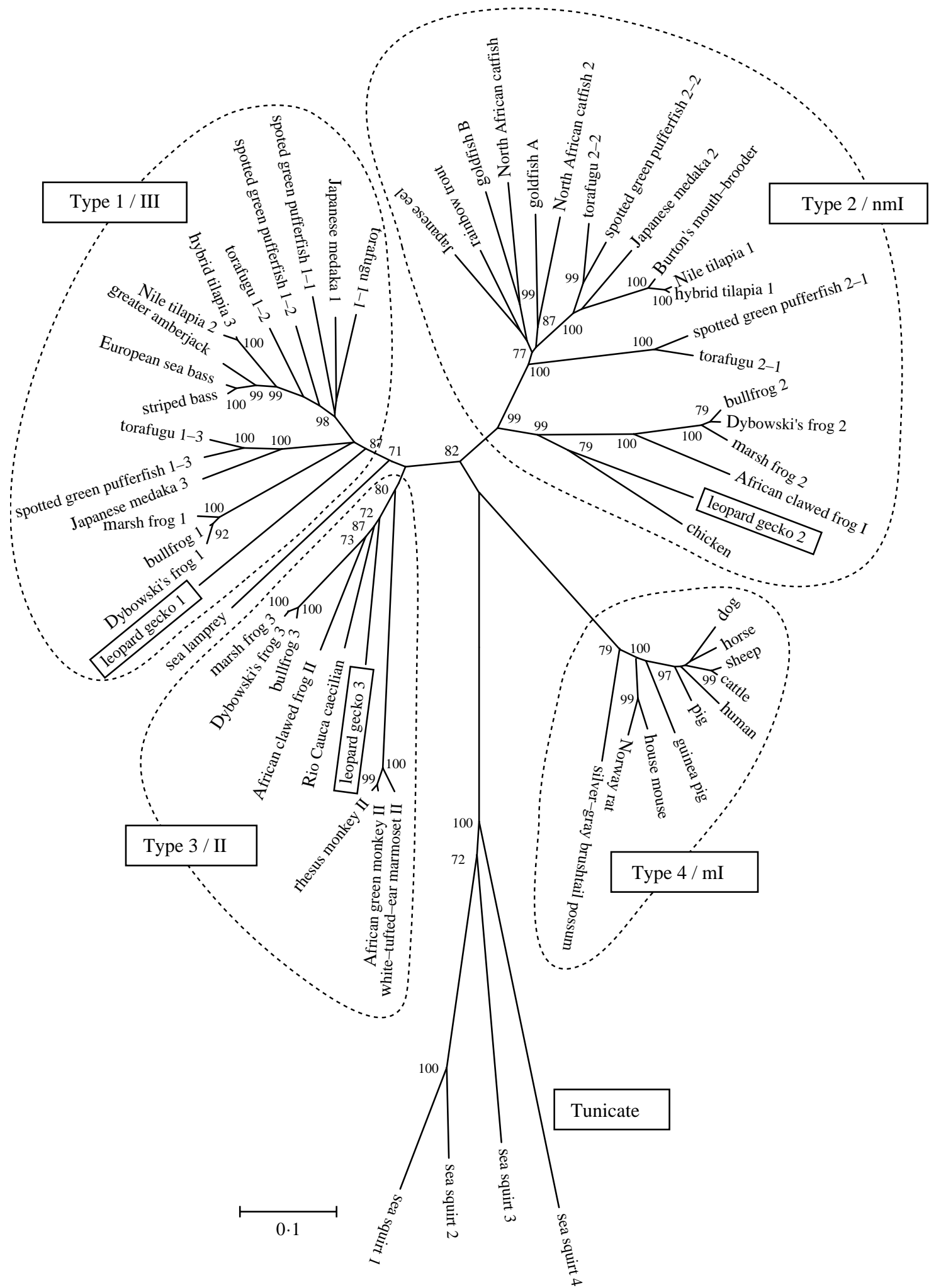

Figure 6 Unrooted neighbor-joining phylogenetic tree of GnRHRs in chordates. The tunicate GnRHRs were used as outgroup. Bootstrap values of 1000 resamplings (over 70 ) are indicated for nodes on the tree. The scale bar corresponds to estimated evolutionary distance units. $\mathrm{m}$, mammalian; $\mathrm{nm}$, non-mammalian. 
Table 3 Amino acid identities (\%) between GnRHRs of the leopard gecko and other representative species

\section{Leopard gecko}

$\mathrm{R} 1 \quad \mathrm{R} 2 \quad \mathrm{R} 3$

Species classification (arabic/roman)

$1 /$ III

$\mathrm{R} 1$

Bullfrog 1

s.g. pufferfish $1-1^{\text {a }}$

s.g. pufferfish 1-2

s.g. pufferfish 1-3

$2 / \mathrm{nml}^{\mathrm{b}}$

R2

Chicken

Bullfrog 2

s.g. pufferfish 2-1

s.g. pufferfish $2-2$

3/II

R3

Bullfrog 3

Rhesus monkey II $4 / \mathrm{ml}^{\mathrm{c}}$

Human I

$\mathrm{a}_{\text {s.g., spotted green }}$

${ }^{b}$ nm, non-mammalian.

${ }^{\mathrm{c}} \mathrm{m}$, mammalian.

with cGnRH-I also resulted in a decrease in estimated $\mathrm{EC}_{50}$ values and the $c$-fos induction at a lower dose (Fig. 11G and Table 4). In contrast, all the other types of co-transfections showed intermediate levels of each single transfection (Fig. 11A, B, E, F, and H).

\section{Discussion}

In the present study, we aimed to clarify the molecular basis underlying the diverse functions of GnRH by examining the gene expression profiles of GnRHRs in a single organism. We identified two GnRH ligands and three GnRHRs from a reptile, the leopard gecko. There has been no study, except ours (Ikemoto \& Park 2003, Ikemoto et al. 2004), identifying full-length genes for $\mathrm{GnRH}$ ligand and receptor in reptiles. It had been hypothesized that reptiles have two GnRHR subtypes, and that one of the three GnRHR subtypes cloned in the present study (type 1/III GnRHR) does not exist in reptiles (Millar 2003). All genes for GnRH ligands and receptors were expressed as full-length mRNAs that would produce functional GnRH decapeptides and heptahelical GnRHRs. Several reports demonstrated the presence of GnRH-like peptides in the brain of lizards (Powell et al. 1985, 1986, Montaner et al. 2000); however, the molecular forms of $\mathrm{GnRH}$ in lizards had remained unidentified because of the nonspecific cross-reactivities of antisera and the lack of peptide sequencing. The present study provided direct evidence of the molecular forms of $\mathrm{GnRH}$ in a reptilian species by gene sequencing, while a study of the American alligator provided such evidence based on peptide sequencing (Lovejoy et al. 1991). The functionality of the cloned receptors was evaluated as described previously (Ikemoto \& Park 2007) using the $c$-fos gene expression, which is conventionally used to monitor cellular activation (Shyamala et al. 1999, Sakurai et al. 2002, Rogers et al. 2005). All three GnRHRs responded to endogenous GnRH ligands, cGnRH-I, and cGnRH-II with distinct maximal potencies and ligand selectivities. This is the first demonstration that reptiles have multiple types of functional GnRHRs. Differences in the pharmacology identified can be due to affinity differences of the receptors to the two GnRHs and/or differences in post-receptor signaling affecting the $c$-fos gene expression.

A number of common features were conserved between the leopard gecko GnRHRs and other species' GnRHRs. In the leopard gecko GnRHRs, several potential sites for $N$-linked glycosylation were found in the amino-terminal extracellular domain. The microdomain $\mathrm{NPX}_{2-3} \mathrm{Y}$ in TM7 is highly conserved in the other rhodopsin $/ \beta_{2}$ adrenergic receptor-like receptors (family A GPCRs). This motif has been reported to be involved in the internalization, agonist-induced receptor activation, and signal transduction of some GPCRs, including GnRHRs (Arora et al. 1996). In all the vertebrate GnRHRs, including the leopard gecko GnRHRs, the asparagine residue of this motif is replaced by an aspartic acid residue (DPXXY). In most family A GPCRs, the two cysteine residues connect the first extracellular loop (EC1) and EC2 for the correct folding of the receptor (Gether 2000). This putative disulfide bridge was conserved in all leopard gecko GnRHRs. The majority of family A GPCRs has a palmitoylated cysteine residue in the carboxy-terminal intracellular domain causing formation of a putative IC4 (Gether 2000). A single or multiple cysteine residues were present in the carboxyl terminus of the leopard gecko GnRHRs. The most highly conserved residues in each helix in the Ballesteros-Weinstein numbering scheme (Ballesteros et al. 1998) were completely conserved in all leopard gecko GnRHRs. The arginine-cage motif, the microdomain DRXXXI/V at the junction of TM3 and IC2, is also highly conserved in family A GPCRs, and the arginine residue is required for efficient signal transduction (Ballesteros \& Weinstein 1995). Most family A GPCRs have a DRY sequence in this motif; however, as in the other species' GnRHRs, the DRY sequence was modified in the leopard gecko GnRHRs (DRQ in GnRHR1, DRH in GnRHR2, and DRR in GnRHR3).

Molecular phylogenetic analysis showed that vertebrate GnRHRs were classified into four groups (types 1/III, 2/nmI, 3/II, and $4 / \mathrm{mI}$ ) as described 


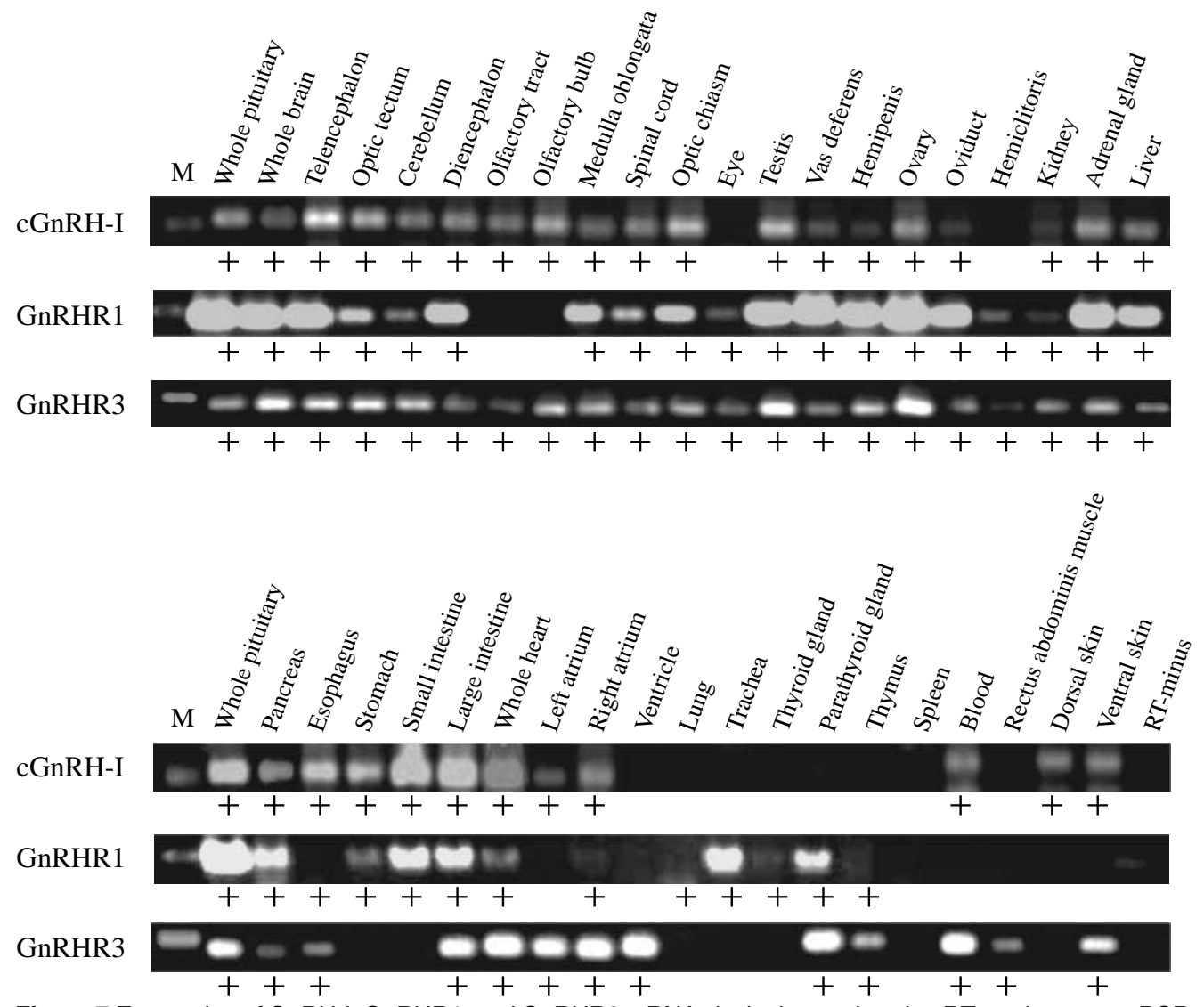

Figure 7 Expression of GnRH-I, GnRHR1, and GnRHR3 mRNAs in the leopard gecko. RT products were PCRamplified to span two exon-intron boundaries, and were analyzed by electrophoresis on agarose gels with ethidium bromide staining. The authenticity of the RT-PCR products was confirmed by direct sequencing of each band of the expected size. The lane labeled RT-minus represents the negative control using a male whole brain RNA sample without the RT reaction. M, molecular marker.

previously (Ikemoto \& Park 2005a). Data presented in Table 3 indicate that the leopard gecko GnRHR3 shares relatively high similarities with type $1 /$ III GnRHRs. Types 1/III and 3/II GnRHRs were located much closer to one another than to other GnRHR subtypes in the phylogenetic tree. This suggests that types' $1 /$ III and 3/II GnRHRs have evolved by duplication of a common ancestral gene. Type 3/II GnRHR has not been identified in bony fish, suggesting that this duplication event had occurred after the fish-tetrapods split, and that type $1 /$ III GnRHR is much more similar to the ancestor. A previous study using genome databases of two pufferfish species strengthens this idea (Ikemoto \& Park 2005a). However, it is also possible and should be further examined that the duplication had occurred before the divergence of vertebrate classes and type 3/II GnRHR had been lost in the fish lineage.

There are several classifications regarding the vertebrate GnRHRs using Roman or Arabic numerals (Troskie et al. 1998, Wang et al. 2001a, Millar et al. 2004). The classification and nomenclature of GnRHRs has not been unified yet. Frequently, the numerical designation of individual cloned GnRHRs in the database does not comply with their phylogenetic affiliation. The decisive difference between the Roman and Arabic classifications is whether mammalian type I GnRHRs is considered the orthologue of non-mammalian type I GnRHRs. This study employs the classification using Arabic numerals along with the Roman numerals. A demonstration of orthologous relationships requires chromosome-wide synteny relationships, not simply sequence similarities. Conservation of synteny is often seen among the genomes of vertebrate species, and this phenomenon allows the definition of orthologous and paralogous relationships (Ogoshi et al. 2003, Ikemoto \& Park 2005b). Therefore, detailed descriptions of synteny relationships will be useful to further investigate the phylogeny and evolution of this diversified GnRHRs.

All the GnRH ligand and receptor mRNAs were expressed in a wide range of tissues of the leopard gecko. This widespread expression is consistent with the previous findings in several species. In the North 


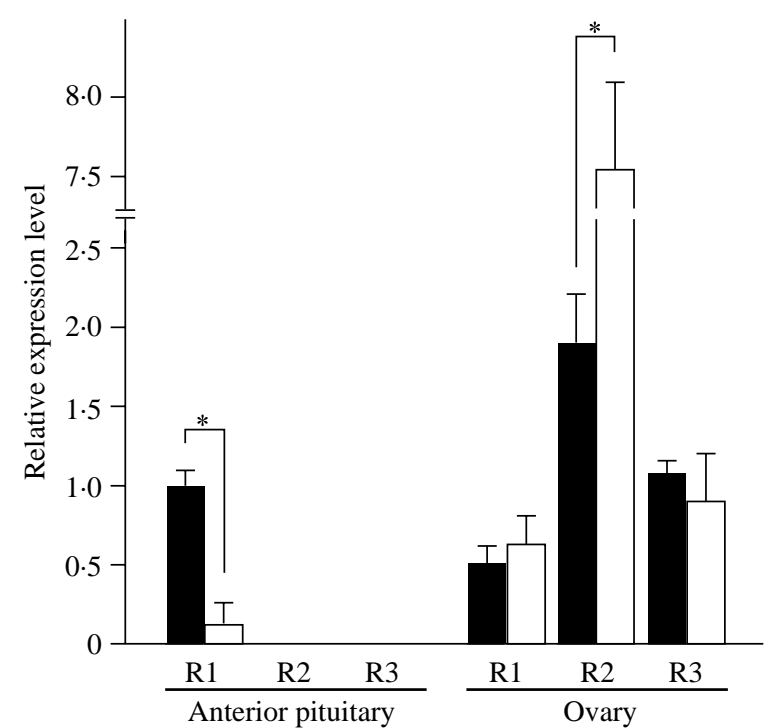

Figure 8 Expression of GnRHRs in the anterior pituitary gland and ovary of the leopard geckos of 1 year of age during (filled boxes) and after the egg-laying season (open boxes). The expression level of GnRHR1 in the anterior pituitary gland during egg-laying season was defined as 1. Data represent the mean \pm S.E.M. from at least three independent samplings. Student's $t$-test was used for statistical analysis. ${ }^{*} P<0.01$.

African catfish, ubiquitous expression of GnRH-II mRNA was observed in all tissues and organs tested (Bogerd et al. 2002). A GnRHR was also ubiquitously expressed in the leopard gecko (Ikemoto et al. 2004). Although the expression of GnRHR mRNA does not ensure that GnRH exerts some function there, the present results support the notion that GnRH may act as a neuromodulator in the brain (Adams \& Brown 1980, Jan et al. 1980, Jones 1987, Oka 2002) and a paracrine and/or an autocrine hormone outside the brain. In addition to the facilitation of gonadotropin secretion, GnRH is thought to have diverse physiological functions, including neuromodulation, gonadal regulation, immunomodulation (Wilson et al. 1995,
Chen et al. 2002), cell proliferation regulation (Schally 1999, Enomoto \& Park 2004), and involvement in regulating other pituitary hormones in bony fish (Marchant et al. 1989, Weber et al. 1997, Mousa \& Mousa 2003, Parhar et al. 2005). It is hypothesized that GnRH plays a paracrine/autocrine role in the regulation of gonadal development and function. Several studies have shown that GnRH agonists induce apoptosis possibly via receotors on granulosa cells in mammalian ovaries (Billig et al. 1994, Parborell et al. 2005). GnRH directly affected oocyte meiosis and follicular steroidogenesis in the goldfish ovary (Pati \& Habibi 2000). Similarly, it has also shown that GnRH induces apoptosis, and may play as a local factor in the control of spermatogenesis in the goldfish testis (Andreu-Vieyra \& Habibi 2001, Andreu-Vieyra et al. 2005). GnRH may directly affect testicular steroidogenesis in the rat and frog (Hsueh et al. 1983, D'Antonio et al. 1992).

It is noteworthy that two of three GnRHR subtypes (GnRHR2 and GnRHR3) could not be detected in the anterior pituitary gland of the leopard gecko. Low or null expression in the pituitary gland has been observed in several non-mammals (Madigou et al. 2000, Wang et al. 2001a, Seong et al. 2003, Ikemoto et al. 2004, Ikemoto \& Park 2005a). These results may suggest the existence of a GnRH system distinct from the wellknown hypothalamic-pituitary-gonadal axis, or the pituitary GnRH system. Both GnRHR2 and GnRHR3 could be detected using the whole pituitary gland but could not be detected using anterior pituitary samples, indicating that they are expressed in the posterior pituitary and/or intermediate lobe.

This study compared the ovarian GnRH system with the pituitary one in the leopard gecko. The decisive difference was the number of GnRHR subtypes expressed. Only one receptor subtype was expressed in the anterior pituitary gland both during and after the egglaying season. Meanwhile, all the three receptor subtypes were expressed in the ovary. The decreased expression of
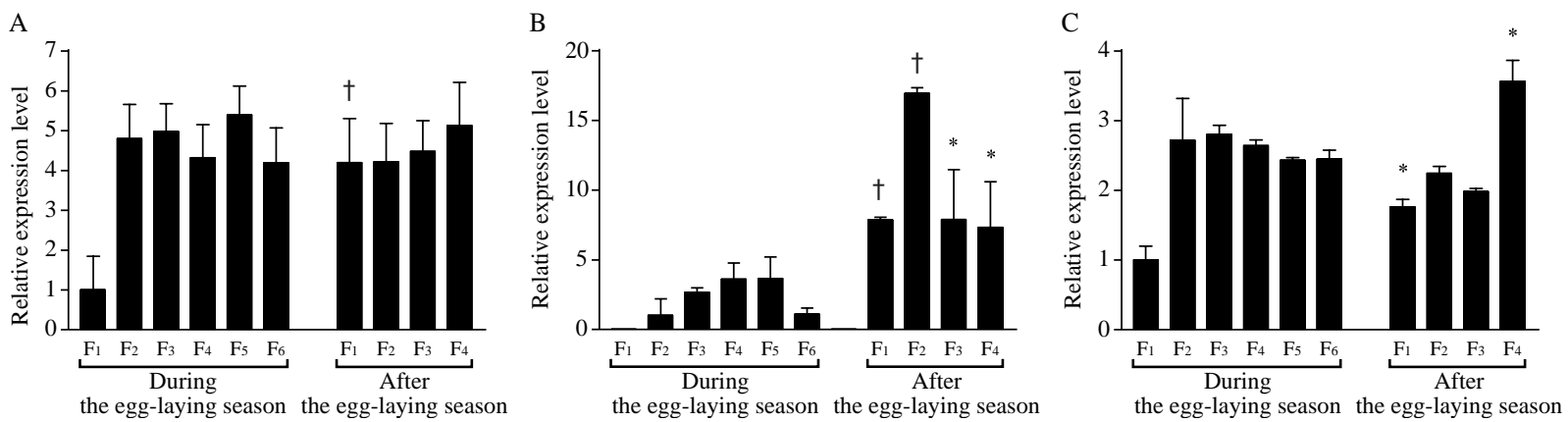

Figure 9 Expression of GnRHR1 (A), GnRHR2 (B), and GnRHR3 (C) mRNAs in the ovarian follicles of the leopard geckos of 1 year of age during and after the egg-laying season. The expression level of the largest follicle $\left(F_{1}\right.$ follicle $)$ during egg-laying season was defined as 1 in $(A)$ and $(C)$, and that of the second largest follicle $\left(F_{2}\right.$ follicle) during egg-laying season was defined as 1 in $(B)$. Data represent the mean \pm S.E.M. from at least three independent samplings. Student's $t$-test was used for statistical analysis. ${ }^{\star} P<0 \cdot 05 ;{ }^{\dagger} P<0 \cdot 01$ (vs each follicle in the corresponding hierarchical order during the egg-laying season). 
A

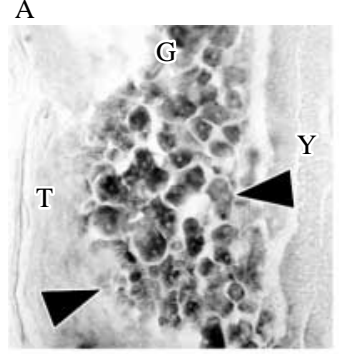

$10 \mu \mathrm{m}$

E

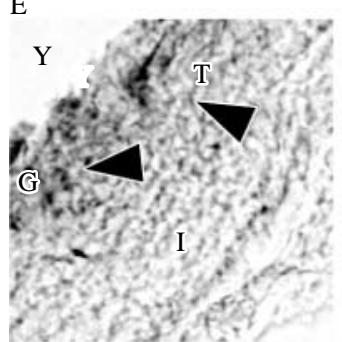

$100 \mu \mathrm{m}$

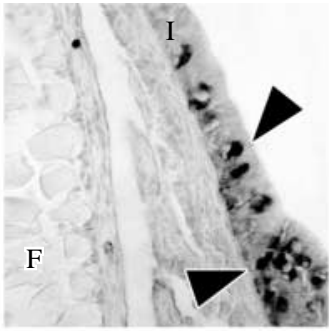

$100 \mu \mathrm{m}$

F

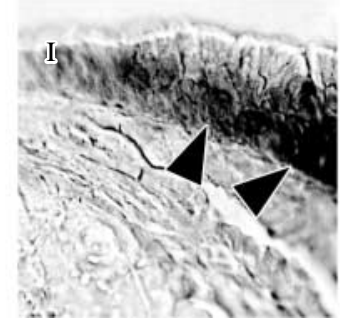

$100 \mu \mathrm{m}$
C

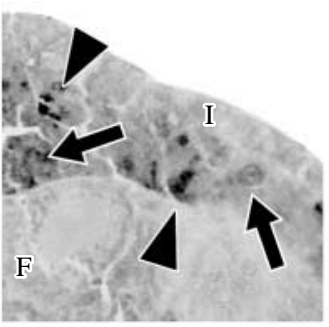

$100 \mu \mathrm{m}$

G

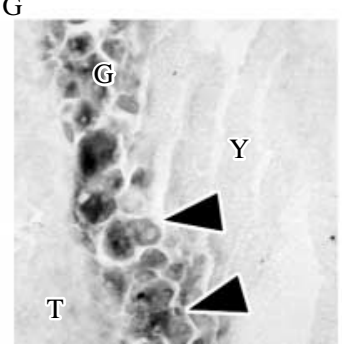

D

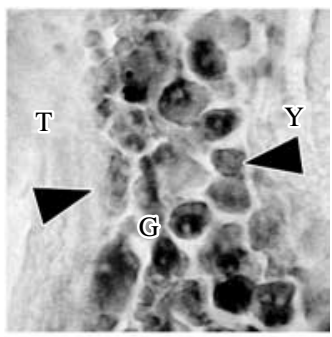

$10 \mu \mathrm{m}$

Figure 10 Spatial expression pattern of the GnRHR1 (A-C), GnRHR2 (D-F), and GnRHR3 $(G)$ mRNAs in the ovary of the leopard geckos of 1 year of age during the egg-laying season. Arrowheads indicate representative signals of hybridization. Arrows indicate immature oocytes. Granulosa cell layers of second largest follicles $\left(F_{2}\right.$ follicles) showed strong signals for all three receptor subtypes $(A, D, G)$. F, follicle; $G$, granulosa cell layer; I, interstitial cells; T, theca cell layer; $Y$, yolk.

A

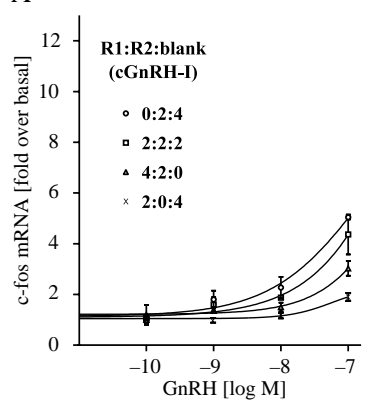

$\mathrm{E}$

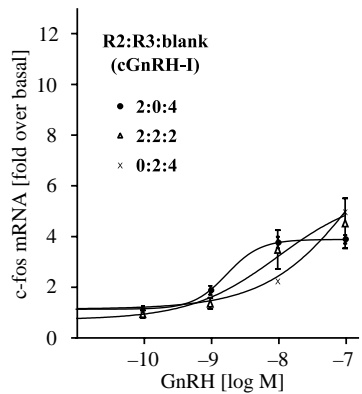

B

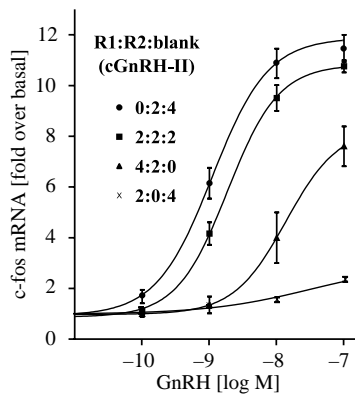

F

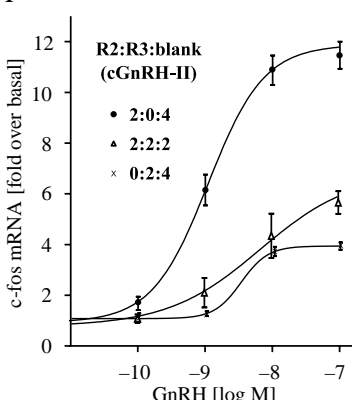

$\mathrm{C}$

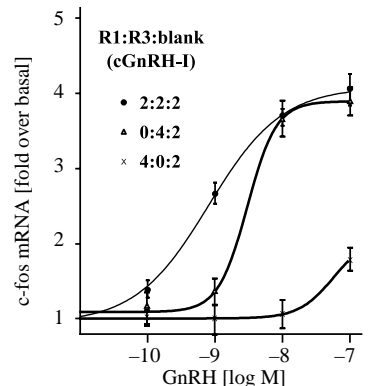

G

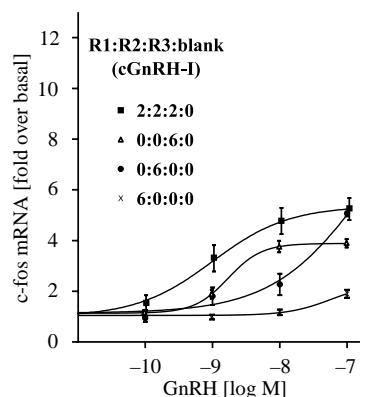

$\mathrm{D}$

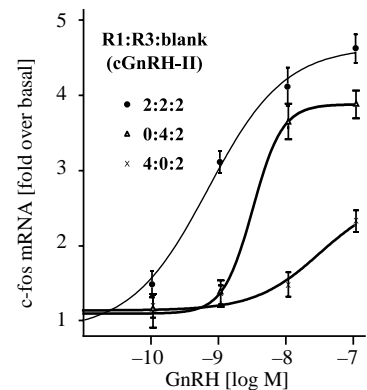

$\mathrm{H}$

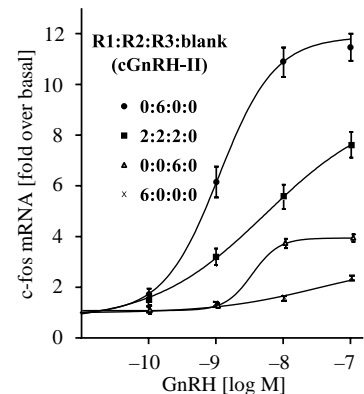

Figure $11 \mathrm{GnRH}$-induced c-fos mRNA expression in COS-7 cells transiently transfected with multiple GnRHR subtypes of the leopard gecko. (A, B,) Co-transfection of GnRHRs 1 and 2; (C, D,) Co-transfection of GnRHRs 1 and 3; (E, F,) Co-transfection of GnRHRs 2 and 3; $(\mathrm{G}, \mathrm{H}$,$) Co-transfection of GnRHRs 1-3$. The total amount of transfected DNA $(6 \mu \mathrm{g})$ was kept constant by the addition of blank vector. Data represent the mean \pm S.E.M. from at least three independent experiments. 
Table $4 \mathrm{GnRH}$-induced c-fos mRNA expression in COS-7 cells transiently transfected with multiple GnRHR subtypes of the leopard gecko

\begin{tabular}{|c|c|c|c|c|}
\hline & Ligand & Ratio ( $\mu \mathrm{g})$ & $\mathrm{EC}_{50}(\mathrm{nM})$ & Max fold induction \\
\hline \multicolumn{5}{|l|}{ Co-transfection } \\
\hline \multirow[t]{8}{*}{ R1:R2:blank } & cGnRH-I & $2: 0: 4$ & $48 \cdot 63 \pm 1 \cdot 81$ & $2.01 \pm 0.26$ \\
\hline & & $0: 2: 4$ & $171 \cdot 6 \pm 23 \cdot 2$ & $10 \cdot 0 \pm 2 \cdot 3$ \\
\hline & & $2: 2: 2$ & $80 \cdot 98 \pm 2.25$ & $6 \cdot 97 \pm 1 \cdot 40$ \\
\hline & & $4: 2: 0$ & $65.99 \pm 2.44$ & $4 \cdot 11 \pm 1 \cdot 73$ \\
\hline & cGnRH-II & $2: 0: 4$ & $29 \cdot 55 \pm 1 \cdot 87$ & $2.67 \pm 0.22$ \\
\hline & & $0: 2: 4$ & $1 \cdot 040 \pm 0.251$ & $11.5 \pm 0.5$ \\
\hline & & $2: 2: 2$ & $1 \cdot 869 \pm 1 \cdot 183$ & $10 \cdot 8 \pm 0 \cdot 4$ \\
\hline & & $4: 2: 0$ & $13 \cdot 82 \pm 2 \cdot 51$ & $8 \cdot 33 \pm 2 \cdot 47$ \\
\hline \multirow[t]{6}{*}{ R1:R3:blank } & cGnRH-I & $4: 0: 2$ & $57 \cdot 49 \pm 5 \cdot 81$ & $2 \cdot 11 \pm 0 \cdot 16$ \\
\hline & & $0: 4: 2$ & $2 \cdot 044 \pm 1 \cdot 454$ & $4 \cdot 07 \pm 0.23$ \\
\hline & & $2: 2: 2$ & $0.8079 \pm 1.4191$ & $4 \cdot 09 \pm 0 \cdot 41$ \\
\hline & cGnRH-II & $4: 0: 2$ & $29 \cdot 56 \pm 6 \cdot 87$ & $2 \cdot 67 \pm 0.22$ \\
\hline & & $0: 4: 2$ & $3.038 \pm 1.53$ & $3.89 \pm 0.20$ \\
\hline & & $2: 2: 2$ & $0.6736 \pm 1.5506$ & $4.64 \pm 0.50$ \\
\hline \multirow[t]{4}{*}{ R2:R3:blank } & cGnRH-I & $0: 2: 4$ & $2 \cdot 044 \pm 1 \cdot 454$ & $4.07 \pm 0.23$ \\
\hline & & $2: 2: 2$ & $10 \cdot 26 \pm 2 \cdot 85$ & $5 \cdot 74 \pm 1 \cdot 12$ \\
\hline & cGnRH-II & $0: 2: 4$ & $3.038 \pm 1.526$ & $3.89 \pm 0.20$ \\
\hline & & $2: 2: 2$ & $6 \cdot 862 \pm 2 \cdot 482$ & $6 \cdot 86 \pm 1 \cdot 22$ \\
\hline \multirow[t]{8}{*}{ R1:R2:R3:blank } & cGnRH-I & $6: 0: 0: 0$ & $56 \cdot 28 \pm 1 \cdot 43$ & $2 \cdot 17 \pm 0.09$ \\
\hline & & $0: 6: 0: 0$ & $156 \cdot 1 \pm 12 \cdot 5$ & $10 \cdot 5 \pm 2 \cdot 6$ \\
\hline & & $0: 0: 6: 0$ & $1 \cdot 784 \pm 1 \cdot 363$ & $3.93 \pm 0.15$ \\
\hline & & $2: 2: 2: 0$ & $0.9557 \pm 1.2457$ & $5.30 \pm 0.48$ \\
\hline & cGnRH-II & $6: 0: 0: 0$ & $22 \cdot 76 \pm 1 \cdot 60$ & $2 \cdot 71 \pm 0 \cdot 14$ \\
\hline & & $0: 6: 0: 0$ & $1 \cdot 104 \pm 1 \cdot 202$ & $11.9 \pm 0.4$ \\
\hline & & $0: 0: 6: 0$ & $3 \cdot 142 \pm 1 \cdot 567$ & $3 \cdot 84 \pm 0 \cdot 14$ \\
\hline & & $2: 2: 2: 0$ & $5 \cdot 467 \pm 2 \cdot 864$ & $9 \cdot 53 \pm 2.03$ \\
\hline
\end{tabular}

GnRHR1 in the anterior pituitary gland after the egglaying season may contribute to the seasonal breeding of the leopard gecko. On the other hand, the ovarian expression of GnRHR2 increased after the egg-laying season. The physiological significance of these changes in the ovary needs to be clarified in further studies.

In our previous studies, the ovarian expression of GnRHR was examined in rats (Kogo et al. 1995, $1999 a, b)$. The results revealed that the expression level of GnRHR increased along with follicular development, and atretic and mature follicles showed the maximum expression. In contrast, the largest $\mathrm{F}_{1}$ follicle in the leopard gecko showed the lowest expression of all three GnRHR subtypes. Difference in the cell type expressing GnRHR mRNA was also detected between rats and leopard gecko. In rats, GnRHR mRNA was predominantly expressed in the granulosa cells, and theca and interstitial cells showed weak or no significant signals. On the other hand in the leopard gecko, GnRHR mRNAs were detected in theca cells, interstitial cells, and immature oocytes in addition to granulosa cells. It will be of great interest to clarify the precise effect of species-specificity in ovarian GnRHR expression.

Multiple receptor subtypes may be co-expressed in granulosa cells of larger follicles in the leopard gecko. Co-transfection of receptor subtypes showed a distinct pharmacology in COS-7 cells compared with those of single transfections. The increase in c-fos expression caused by co-transfection of GnRHR1 and GnRHR3 and of three GnRHR subtypes may indicate the existence of interaction and signaling crosstalk between multiple GnRHR subtypes. It has been reported that the GnRHR signaling was inhibited by co-expression of its splice variant in humans and bullfrog (Grosse $\mathrm{et} \mathrm{al}$. 1997, Wang et al. 2001b). The present results demonstrated the existence of functional interactions between multiple GnRHR subtypes. Collectively, these results suggest that distinct signaling mechanisms are involved in the pituitary and ovarian GnRH systems.

In conclusion, the present study identified GnRH ligands and receptors, and described the pituitary and ovarian GnRH systems in the leopard gecko. The fact that two of three GnRHR subtypes could not be detected in the anterior pituitary gland suggested the existence of a GnRH system distinct from the wellknown pituitary GnRH system. It was also suggested that the hypothalamic GnRH stimulates pituitary gonadotropes to release gonadotropins via GnRHR1 in the leopard gecko. Differences in the expression patterns of GnRHR subtypes were observed between the anterior pituitary gland and ovary. The subtype and combination of GnRHRs expressed can influence and differentiate between cGnRH-I and cGnRH-II actions, and there are likely interactions between the different GnRHR subtypes. This is the first study describing the 
expression profile of multiple GnRHRs from different phylogenetic origins during the seasonal changes in the pituitary and ovary of any species. The present study also demonstrated the first quantitative differences in GnRHR expression among follicles arranged in a hierarchy inside individual ovaries. Seasonal and developmental variations in receptor expression detected in the anterior pituitary gland and ovarian follicles may contribute to the seasonal breeding of this animal. Further characterization of GnRH's role in the ovary will provide insights into the biological significance of the complex physiology of GnRH systems.

\section{Acknowledgements}

The authors are sincerely grateful to Prof. Y Oka, Dr Y Akazome, Dr $\mathrm{H}$ Abe, Ms M Kyokuwa, and Dr M Enomoto for their helpful discussions and comments on the present study. The authors also express their deepest gratitude to Ms Ki for continuous encouragement and insightful criticisms throughout the work.

\section{Funding}

This work was supported by the Grants-in-Aid for Research Fellow of the Japan Society for the Promotion of Science from the Ministry of Education, Culture, Sports, Science, and Technology to $\mathrm{T} \mathrm{I}$ and by the Grants-in-Aid for Scientific Research from the Japan Society for the Promotion of Science to M K P. The authors declare that there is no conflict of interest that would prejudice its impartiality.

\section{References}

Adams PR \& Brown DA 1980 Luteinizing hormone-releasing factor and muscarinic agonists act on the same voltage-sensitive $\mathrm{K}^{+}$current in bullfrog sympathetic neurones. British Journal of Pharmacology 68 353-355.

Andreu-Vieyra CV \& Habibi HR 2001 Effects of salmon GnRH and chicken GnRH-II on testicular apoptosis in goldfish (Carassius auratus). Comparative Biochemistry and Physiology. Part B, Biochemistry and Molecular Biology 129 483-487.

Andreu-Vieyra CV, Buret AG \& Habibi HR 2005 Gonadotropinreleasing hormone induction of apoptosis in the testes of goldfish (Carassius auratus). Endocrinology 146 1588-1596.

Arora KK, Cheng Z \& Catt KJ 1996 Dependence of agonist activation on an aromatic moiety in the DPLIY motif of the gonadotropinreleasing hormone receptor. Molecular Endocrinology 10 979-986.

Ballesteros JA \& Weinstein H 1995 Integrated methods for the construction of three-dimensional models and computational probing of structure-function relations in $\mathrm{G}$ protein coupled receptors. Methods in Neuroscience 25 366-428.

Ballesteros J, Kitanovic S, Guarnieri F, Davies P, Fromme BJ, Konvicka K, Chi L, Millar RP, Davidson JS, Weinstein H et al. 1998 Functional microdomains in G-protein-coupled receptors. The conserved arginine-cage motif in the gonadotropin-releasing hormone receptor. Journal of Biological Chemistry 273 10445-10453.
Billig H, Furuta I \& Hsueh AJ 1994 Gonadotropin-releasing hormone directly induces apoptotic cell death in the rat ovary: biochemical and in situ detection of deoxyribonucleic acid fragmentation in granulosa cells. Endocrinology 134 245-252.

Bogerd J, Diepenbroek WB, Hund E, van Oosterhout F, Teves AC, Leurs R \& Blomenrohr M 2002 Two gonadotropin-releasing hormone receptors in the African catfish: no differences in ligand selectivity, but differences in tissue distribution. Endocrinology 143 4673-4682.

Burgus R, Butcher M, Amoss M, Ling N, Monahan M, Rivier J, Fellows R, Blackwell R, Vale W \& Guillemin R 1972 Primary structure of the ovine hypothalamic luteinizing hormone-releasing factor (LRF). PNAS 69 278-282.

Chen A, Ganor Y, Rahimipour S, Ben-Aroya N, Koch Y \& Levite M 2002 The neuropeptides GnRH-II and GnRH-I are produced by human T cells and trigger laminin receptor gene expression, adhesion, chemotaxis and homing to specific organs. Nature Medicine 8 1421-1426.

D’Antonio M, Fasano S, de Leeuw R \& Pierantoni R 1992 Effects of gonadotropin-releasing hormone variants on plasma and testicular androgen levels in intact and hypophysectomized male frogs, Rana esculenta. Journal of Experimental Zoology 261 34-39.

Douglass J, Civelli O \& Herbert E 1984 Polyprotein gene expression: generation of diversity of neuroendocrine peptides. Annual Review of Biochemistry 53 665-715.

Enomoto M \& Park MK 2004 GnRH as a cell proliferation regulator: mechanism of action and evolutionary implications. Zoological Science 21 1005-1013.

Gether U 2000 Uncovering molecular mechanisms involved in activation of G protein-coupled receptors. Endocrine Reviews 21 90-113.

Grosse R, Schoneberg T, Schultz G \& Gudermann T 1997 Inhibition of gonadotropin-releasing hormone receptor signaling by expression of a splice variant of the human receptor. Molecular Endocrinology 11 1305-1318.

Hsueh AJ, Bambino TH, Zhuang LZ, Welsh TH Jr \& Ling NC 1983 Mechanism of the direct action of gonadotropin-releasing hormone and its antagonist on androgen biosynthesis by cultured rat testicular cells. Endocrinology 112 1653-1661.

Ikemoto T \& Park MK 2003 Identification and characterization of the reptilian $G n R H-I I$ gene in the leopard gecko, Eublepharis macularius, and its evolutionary considerations. Gene 316 157-165.

Ikemoto T \& Park MK $2005 a$ Identification and molecular characterization of three GnRH ligands and five $\mathrm{GnRH}$ receptors in the spotted green pufferfish. Molecular and Cellular Endocrinology 242 67-79.

Ikemoto T \& Park MK $2005 b$ Chicken RFamide-related peptide $(\mathrm{GnIH})$ and two distinct receptor subtypes: identification, molecular characterization, and evolutionary considerations. Journal of Reproduction and Development 51 359-377.

Ikemoto T \& Park MK 2006 Molecular and evolutionary characterization of the $G n R H-I I$ gene in the chicken: distinctive genomic organization, expression pattern, and precursor sequence. Gene 368 28-36.

Ikemoto T \& Park MK 2007 A system for receptor functional analysis based on c-fos mRNA expression: analysis of $\mathrm{GnRH}$ receptors as a test system. Journal of Biochemical and Biophysical Methods (In Press).

Ikemoto T, Enomoto M \& Park MK 2004 Identification and characterization of a reptilian GnRH receptor from the leopard gecko. Molecular and Cellular Endocrinology 214 137-147.

Jan LY, Jan YN \& Brownfield MS 1980 Peptidergic transmitters in synaptic boutons of sympathetic ganglia. Nature 288 380-382.

Jones SW 1987 Chicken II luteinizing hormone-releasing hormone inhibits the M-current of bullfrog sympathetic neurons. Neuroscience Letters 80 180-184.

Kogo H, Kudo A, Park MK, Mori T \& Kawashima S 1995 In situ detection of gonadotropin-releasing hormone $(\mathrm{GnRH})$ receptor mRNA expression in the rat ovarian follicles. Journal of Experimental Zoology 272 62-68. 
Kogo H, Fujimoto T \& Mori T $1999 a$ Evidence for gonadotropinreleasing hormone receptor mRNA expression by estrogen in rat granulosa cells. Cell and Tissue Research 297 459-465.

Kogo H, Fujimoto T, Park MK \& Mori T $1999 b$ Gonadotropin-releasing hormone receptor mRNA expression in the ovaries of neonatal and adult rats. Cells, Tissues, Organs 164 14-22.

Kumar S, Tamura K \& Nei M 2004 MEGA3: integrated software for molecular evolutionary genetics analysis and sequence alignment. Briefings in Bioinformatics 5 150-163.

Lovejoy DA, Fischer WH, Parker DB, McRory JE, Park M, Lance V, Swanson P, Rivier JE \& Sherwood NM 1991 Primary structure of two forms of gonadotropin-releasing hormone from brains of the American alligator (Alligator mississippiensis). Regulatory Peptides $\mathbf{3 3}$ 105-116.

Madigou T, Mananos-Sanchez E, Hulshof S, Anglade I, Zanuy S \& Kah O 2000 Cloning, tissue distribution, and central expression of the gonadotropin-releasing hormone receptor in the rainbow trout (Oncorhynchus mykiss). Biology of Reproduction 63 1857-1866.

Marchant TA, Chang JP, Nahorniak CS \& Peter RE 1989 Evidence that gonadotropin-releasing hormone also functions as a growth hormone-releasing factor in the goldfish. Endocrinology 124 2509-2518.

Matsuo H, Baba Y, Nair RM, Arimura A \& Schally AV 1971 Structure of the porcine LH- and FSH-releasing hormone. I. The proposed amino acid sequence. Biochemical and Biophysical Research Communications 43 1334-1339.

Millar RP 2003 GnRH II and type II GnRH receptors. Trends in Endocrinology and Metabolism: TEM 14 35-43.

Millar RP, Lu ZL, Pawson AJ, Flanagan CA, Morgan K \& Maudsley SR 2004 Gonadotropin-releasing hormone receptors. Endocrine Reviews 25 235-275.

Montaner AD, Gonzalez O, Paz DA, Affanni JM \& Somoza GM 2000 Gonadotropin-releasing hormone $(\mathrm{GnRH})$ variants in a lizard brain: is mammalian GnRH being expressed? General and Comparative Endocrinology 119 121-131.

Mount SM 1982 A catalogue of splice junction sequences. Nucleic Acids Research 10 459-472.

Mousa MA \& Mousa SA 2003 Immunohistochemical localization of gonadotropin releasing hormones in the brain and pituitary gland of the Nile perch, Lates niloticus (Teleostei, Centropomidae). General and Comparative Endocrinology 130 245-255.

Ogoshi M, Inoue K \& Takei Y 2003 Identification of a novel adrenomedullin gene family in teleost fish. Biochemical and Biophysical Research Communications 311 1072-1077.

Oka Y 2002 Physiology and release activity of GnRH neurons. Progress in Brain Research 141 259-281.

Okubo K, Mitani H, Naruse K, Kondo M, Shima A, Tanaka M, Asakawa S, Shimizu N, Yoshiura Y \& Aida K 2002 Structural characterization of GnRH loci in the medaka genome. Gene 293 181-189.

Parborell F, Irusta G, Vitale A, Gonzalez O, Pecci A \& Tesone M 2005 Gonadotropin-releasing hormone antagonist antide inhibits apoptosis of preovulatory follicle cells in rat ovary. Biology of Reproduction 72 659-666.

Parhar IS, Ogawa S \& Sakuma Y 2005 Three GnRH receptor types in laser-captured single cells of the cichlid pituitary display cellular and functional heterogeneity. PNAS 102 2204-2209.

Pati D \& Habibi HR 2000 Direct action of GnRH variants on goldfish oocyte meiosis and follicular steroidogenesis. Molecular and Cellular Endocrinology 160 75-88.
Powell RC, King JA \& Millar RP 1985 [Trp7,Leu8]LH-RH in reptilian brain. Peptides 6 223-227.

Powell RC, Ciarcia G, Lance V, Millar RP \& King JA 1986 Identification of diverse molecular forms of $\mathrm{GnRH}$ in reptile brain. Peptides 7 1101-1108.

Rogers A, Schmuck G, Scholz G, Griffiths R, Meredith C, Schousboe A, Campiani G \& Williams DC 2005 Improvements in an in vitro assay for excitotoxicity by measurement of early gene ( $c$-fos mRNA) levels. Archives of Toxicology 79 129-139.

Saitou N \& Nei M 1987 The neighbor-joining method: a new method for reconstructing phylogenetic trees. Molecular Biology and Evolution 4 406-425.

Sakurai S, Alam S, Pagan-Mercado G, Hickman F, Tsai JY, Zelenka P \& Sato S 2002 Retinal capillary pericyte proliferation and $c$-Fos mRNA induction by prostaglandin $\mathrm{D}_{2}$ through the cAMP response element. Investigative Ophthalmology and Visual Science 43 2774-2781.

Schally AV 1999 Luteinizing hormone-releasing hormone analogs: their impact on the control of tumorigenesis. Peptides 20 1247-1262.

Seong JY, Wang L, Oh DY, Yun O, Maiti K, Li JH, Soh JM, Choi HS, Kim K, Vaudry H et al. $2003 \mathrm{Ala} / \mathrm{Thr}(201)$ in extracellular loop 2 and Leu/Phe(290) in transmembrane domain 6 of type 1 frog gonadotropin-releasing hormone receptor confer differential ligand sensitivity and signal transduction. Endocrinology 144 454-466.

Shyamala V, Khoja H, Anderson ML, Wang JX, Cen H \& Kavanaugh WM 1999 High-throughput screening for ligand-induced $\mathrm{c}$-fos mRNA expression by branched DNA assay in Chinese hamster ovary cells. Analytical Biochemistry 266 140-147.

Thompson JD, Gibson TJ, Plewniak F, Jeanmougin F \& Higgins DG 1997 The CLUSTAL_X windows interface: flexible strategies for multiple sequence alignment aided by quality analysis tools. Nucleic Acids Research 25 4876-4882.

Troskie B, Illing N, Rumbak E, Sun YM, Hapgood J, Sealfon S, Conklin D \& Millar R 1998 Identification of three putative GnRH receptor subtypes in vertebrates. General and Comparative Endocrinology 112 296-302.

Wang L, Bogerd J, Choi HS, Seong JY, Soh JM, Chun SY, Blomenrohr M, Troskie BE, Millar RP, Yu WH et al. 2001 a Three distinct types of GnRH receptor characterized in the bullfrog. PNAS 98 361-366.

Wang L, Oh DY, Bogerd J, Choi HS, Ahn RS, Seong JY \& Kwon HB $2001 b$ Inhibitory activity of alternative splice variants of the bullfrog GnRH receptor-3 on wild-type receptor signaling. Endocrinology 142 4015-4025.

Weber GM, Powell JF, Park M, Fischer WH, Craig AG, Rivier JE, Nanakorn U, Parhar IS, Ngamvongchon S, Grau EG et al. 1997 Evidence that gonadotropin-releasing hormone $(\mathrm{GnRH})$ functions as a prolactin-releasing factor in a teleost fish (Oreochromis mossambicus) and primary structures for three native GnRH molecules. Journal of Endocrinology 155 121-132.

Wilson TM, Yu-Lee LY \& Kelley MR 1995 Coordinate gene expression of luteinizing hormone-releasing hormone (LHRH) and the LHRH-receptor after prolactin stimulation in the rat Nb2 T-cell line: implications for a role in immunomodulation and cell cycle gene expression. Molecular Endocrinology 9 44-53.

Received in final form 11 November 2006

Accepted 4 December 2006

Made available online as an Accepted Preprint 12 December 2006 